\title{
GEOGRAFSKA PROBLEMATIKA LJUBLJANE IN ZAGREBA
}

Vsaki dve leti se izmenično v Sloveniji ali na Hrvaškem srečajo sodelavci Oddelka za geografijo Filozofske fakultete Univerze v Ljubljani in Odseka za geografijo Prirodoslovno matematične fakultete Univerze $\mathrm{v}$ Zagrebu na tematsko opredeljenem znanstvenem seminarju. 15. in 16. aprila 2004 je bila na takšnem seminar ju v Ljubljani obravnavana problematika Ljubljane in Zagreba, dveh novih državnih prestolnic $\mathrm{z}$ vsemi njunimi razvojnimi značilnostmi. Seminarja se je na Oddelku za geografijo Filozofske fakultete udeležilo okrog 50 sodelavcev obeh Oddelkov in drugih slovenskih geografskih ter sorodnih institucij, uporabnikov in podiplomskih študentov.

Bil je kar zadnji čas, da je prišla, po vrsti v regionalno razvojnih problematik, v obravnavo problematika mest, še posebej obeh prestolnic. Prestolnice so središča ekonomskih koncentracij in razvoja, kar hitro spreminja mestni prostor $\mathrm{v}$ vseh njegovih pogledih in seveda tudi strukturo, tako funkcionalno kot socialno. Glede na to, da je geografsko raziskovalno zanimanje za urbano problematiko in še posebej za obe prestolnici, tudi glede na potrebe prakse, daleč preskromno, je že dvanajst predstavljenih referatov velik uspeh tega znanstvenega srečanja. Tematike so bile zelo raznolike od položaja Zagreba v omrežju evropskih mest, regionalno razvojne problematike Ljubljanske urbane regije, o funkcijski zgradbi Ljubljane, o oskrbnih središčih $\vee$ Zagrebu ter spreminjanja rabe tal v Ljubljani, do vloge kolodvorskih predelov v razvoju Zagreba, pomena prometa za ljubljansko mestno aglomeracijo, vloge preseljevanja v razvoju zagrebške mestne regije, razvoja prebivalstva v Ljubljanski mestni regiji, preobrazbe zagrebške mestne regije, še posebej na primeru občine Bistra in kriminalitete kot vse pomembnejšega dejavnika kvalitete bivanja $v$ Ljubljanski mestni regiji.

Vrsta izredno aktualnih problematik razvoja obeh prestolnic z izjemno razvojno dinamiko seveda ni mogla biti obravnavana. So pa sami referati in razprava nedvomno prispevali $\mathrm{k}$ dvigu kvalitete tovrstnih geografskih raziskovanj, $\mathrm{k}$ šijenju kroga geografov, ki se bodo ukvarjali s to problematiko in s tem nedvomno $\mathrm{k}$ tehtnejšemu prispevku geografije $\mathrm{v}$ proučevanjih obeh "velemest" ter s tem tudi prispevka slovenske in hrvaške geografije tako na urbanogeografskem področju kakor v praksi.

Drugi dan seminarja je bil posvečen preverjanju posameznih problematik v Ljubljani in na vzhodnem obrobju Mestne občine Ljubljana.

Referati znanstvenega srečanja so tiskani v znanstveni reviji DELA 22, ki je ob dveh novejših delih, Zborniku referatov z zborovanja slovenskih geografov "Ljubljana - geografija mesta" (2000), ki ga je izdalo Ljubljansko geografsko društvo in monografiji "Geografija Ljubljane" (2002), ki jo je izdal Oddelek za geografijo Filozofske fakultete v Ljubljani, kar znaten prispevek $\mathrm{k}$ geografskemu orisu Ljubljane.

Mirko Pak 